\title{
THE CONCEPT OF INFORMATION SECURITY IN THE CONTEXT OF THE SCIENCE OF PUBLIC ADMINISTRATION
}

\author{
Yaroslav Chmyr ${ }^{1}$ \\ ${ }^{1}$ Graduate student of the Department of Public Administration of the Interregional Academy of Personnel \\ Management, Kyiv, Ukraine, e-mail: jaroslawcm@ukr.net,ORCID: https://orcid.org/0000-0002-4476-6687
}

\begin{abstract}
The article summarizes the views of the Ukrainian scientists on the essence, content and functions of information security, gives the author's vision of this societal phenomenon. The aim of article is to reveal the ontological essence and components of the societal phenomenon "information policy" in the context of the science of public administration. The author used the methods of logical comparison, systematization and generalization, which made it possible to achieve the goal of the study. It is noted that the information space of the state as an integral part of the global information space of mankind is an important system-forming factor of the modern statehood and includes both broad opportunities for access to information, operation and use for their own purposes, and unprecedented opportunities and abuse, in principle new forms of crime, which raises the issue of information security of the state. It is concluded that information security in a globalized information society plays a key role in the further civilizational development of mankind, as modern information security means not only and not so much technical and technological measures to protect the information systems and networks, identify and eliminate various information threats, how much protection of the national information sovereignty of the state, information interests of the society and man, maintenance of the socio-political, spiritual-cultural, moral-ethical and other interests of the citizens functioning in the information space, stability of the state system and political system of the country.
\end{abstract}

Keywords: public administration, information security, information society, information technologies, state information policy.

JEL Classification: C80, H55, H79, K24

Formulas: 0; fig.:0; tabl.:0; bibl.: 14

Introduction. The main characteristic of modernity is the deep penetration of information systems and information and communication technologies in all spheres of the human life, society, the state and the growing influence of the information society on the state of public relations and processes, especially the realization of personal, social and national interests. The information revolution, having just begun, has already led to the dependence of man on the computer and smartphone - at work, at leisure, in communication, education, learning about the world. Simultaneously with the wide possibilities of access to information, its use and use for their own purposes, previously unseen opportunities and its abuse have opened up, fundamentally new forms of crime, such as hacking, theft of confidential information, burglary of the banking system to steal funds, electronic industrial espionage, theft from networks of the public authorities of state secrets, telephone conversations of the first persons of the state, implementation by means of electronic networks of separatist, extremist and terrorist activity.

Thus, the information space of the state as an integral part of the global information space of mankind is an important system-forming factor of the modern state formation, regulation of the social and power relations, which comprehensively affects the state and development of defense, political, economic, social, spiritual, cultural and other components of the national security of the state, and therefore - the 
growing importance and role of information security of man, society and the state as a central element of the national security.

Literature Review. This trend of civilizational progress is emphasized by the Ukrainian researchers M. Nikiforov, I. Pampukha and V. Loza, who emphasize that "today the information struggle is becoming one of the main forms of resolving conflicts between the states... No war can be won until victory is won on the information front. You can have or get state-of-the-art weapons, win a battle, but the final victory in the war without victory on the information front of the struggle for public consciousness is impossible to achieve" [7, p. 139]. The importance of information security in the modern world is emphasized by our compatriot A. Turchak, who believes that "the states that are unable to ensure their own information security, become uncompetitive and, as a result, lose the ability to fight for markets and resources" [12, p. 45]. To a greater or lesser extent, the issue of information security is raised by such Ukrainian scientists as M. Hnatko, O. Kyrychenko, I. Korzh, L. Kochubey, Ye. Manuilov, Yu. Kalynovsky, M. Nikiforov, O. Nishchymenko, O. Oliynyk, P. Snitsarenko, V. Toryanyk, A. Turchak, V. Furashev and others.

Aims. The aim of the article is to reveal the ontological essence and components of the societal phenomenon "information policy" in the context of the science of public administration.

Methods. The author used the methods of logical comparison, systematization and generalization, which made it possible to achieve the goal of the study.

Results. The existing contradictions between the states and civilizations in the world intensify their information confrontation to the point of information war, trying to destabilize all the processes of the social life of the opponent, undermine his state system, sow discord in the society by promoting and supporting the ideas of separatism, xenophobia, extremism, radical nationalism, religious fanaticism, etc. all that undermines the national unity and threatens the true interests of the man, society and the state in general and in the information sphere in particular. Consequently, modern states make significant efforts to protect their national interests, especially in the information sphere. As O. Nishchymenko notes, "protecting its information interests, Ukraine must take care of its information security, the same is required for the strengthening of the Ukrainian statehood" [8, p. 17]. However, according to experts, due to very poorly defined mechanisms for protecting and defending the main information national interests of the state, the Doctrine of Information Security of Ukraine adopted in Ukraine looks like an empty declaration [1] rather than a strategic state document, which determines the activities of the public authorities and society in this area.

Along with the lack of mechanisms to protect our information interests, according to military experts P. Snitsarenko, Yu. Sarychev and V. Tkachenko "to date, the problem of developing the theoretical foundations of the information security of Ukraine remains unsolved, where the main obstacle should be considered underdevelopment, imperfection and inconsistency of the terminological base. This slows down the general process of creating a full-fledged theory of this subject area 
and does not allow in today's dynamic conditions of the information processes to most rationally implement practical measures" [10, p. 62].

Thus, first of all, there is the task of determining the ontological essence and content of the societal phenomenon "information security". The absence in the scientific discourse of a generally accepted definition presupposes the existence of many quite different scientific points of view on this phenomenon. Thus, V. Toryanyk defines information security as "a state of security of the information space, which ensures the formation and development of this space in the interests of the individual, society and the state" [11, p. 153]; Ye. Manuilov and Yu. Kalynovsky - as the protection of the vital interests of the man and citizen, society and the state, which ensures sustainable development of the society, timely detection, prevention and neutralization of real and potential threats to the national interests in the fields of science and technology and innovation policy, cultural development of the population, ensuring freedom of speech and information security, protection of information, communication, information technologies in the event of negative tendencies to create potential or real threats to the national interests" [6, p. 15].

A. Turchak considers information security "as a state in which the vital personal, public and state interests are protected, losses caused by incompleteness, untimeliness and inaccuracy of information, negative information impact, negative consequences of the functioning of technologies in the information sphere, as well as unauthorized dissemination of data are minimized" [12, p. 46]. V. Furashev provides a comprehensive interpretation of information security as "a state of protection of the vital interests of the man, society and the state, which prevents harm through: negative information impact through, first of all, unauthorized creation, dissemination, use of incomplete, untimely, unreliable and biased information deliberately aimed at a specific purpose; negative consequences of the use of the information technology; unauthorized violation of the regime of access to information with its further dissemination and use" [13, p.164].

Summarizing the views of the Ukrainian scholars, we will try to provide an integrative definition of "information security" as a certain stable state of the society that provides reliable and maximum protection of the information needs and interests of the individuals, local communities, society and the state, the entire infrastructure of the national information space from the harmful effects of natural and man-made threats of a special information and communication type, aimed at undermining the legitimacy of the public administration and destabilizing the socio-political system, deformation of the socio-power relations, increasing the socio-political and psychological tensions in the society, inhibition of the social progress and civilizational development of the state.

Highlighting the national information space as a substantial basis for the concept of information security of the state and defining the man, territorial communities, society as a whole and the state, embodied by the public authorities as the main actors of the information space and information security, we can talk about the principles and functions of the information security. In relation to the information security as a relevant scientific theory and tasks of the public authorities in their activities to 
ensure the information security of the state "principles of the information security are the starting point for the formation and functioning of the information security as a system-forming factor of all the components of the national security, norms and rules of conduct of the citizens, state and public institutions of Ukraine in this area" [9, p. 77].

If the principle is a rule that underlies the activities of a particular organization, the main objectives of such activities are defined as functions. In particular, I. Korzh notes that "the information activity of the state on the implementation of the relevant tasks mediates its information function, which has a complex nature. In the general information function of the state it is possible to allocate such its integral component as information and security function under which the direction and the party of activity of the state expressing its essence and social purpose concerning the maintenance of security of the state and storage of information related to the state security)" [4, p. 111].

O. Kyrychenko calls the following the main functions of the state in ensuring information security:

- adoption and implementation of state legislative regulations that create a regulatory framework for the information security of the state;

- formation of actions aimed at providing information resources; regulation of the processes of formation of information resources;

- development and implementation of the principles of the state information policy and regulation of the information security processes of the state;

- state registration of the information resources;

- creating conditions for safe and efficient use of the information resources;

- creation of conditions for normative-legal, material-technical, productiontechnological maintenance of the security and development of the information processes in Ukraine;

- providing the conditions necessary for the creation and promotion of the information technology, information infrastructure and efficient use of the information resources;

- implementation of state programs for the creation and development of the information society and the security of its functioning;

- creation of mechanisms to ensure the security of the information resources;

- state regulation in the field of information cooperation in the use of information resources within the state and in the international information space;

- formation and implementation of information and information and communication policy of the state, information and analytical support in the field of the information resources management;

- staffing in the field of the information resources management [3, p. 21].

In turn, the functions of any system, body, institution are detailed in the relevant functional tasks. Since the main subject of the information security of the state are the public authorities, so the main tasks to ensure information security of the state are entrusted to them. Such tasks in conditions of modern Ukraine are: 
- legislative definition of the essence of the state information policy of Ukraine on the basis of a clear and correct conceptual apparatus and clarification of the directions of its implementation, the main of which should be ensuring the information security of the state (P. Snitsarenko, Yu. Sarychev and V. Tkachenko $[10$, p. 66]);

- development of a regulatory framework that would regulate the solution of all the tasks related to the information protection;

- creation of a system of structures that would be responsible for maintaining the information security and addressing issues related to information protection and automation;

- high-quality informing of people and free access to various information databases, with the possibility of controlling actions on non-dissemination of classified information;

- maintaining the society intact, protection from any negative information impact;

- organization of training of specialists in the relevant specialty (A. Turchak [12, p. 46]);

- balance of the state policy of the information security of Ukraine on the basis of the legal democratic state, development and realization of the corresponding national doctrines, strategies, concepts and programs according to the current legislation (O. Nishchymenko [8, p. 22]);

- consistency and continuity of the process of organizing the activities of the state in matters of information security, aimed at developing and implementing legal, organizational, technical and other measures in this area (L. Kochubey [5, p. 22]);

- subjectively, expediently, consciously, consistently and purposefully to influence the level of the national security of the state through appropriate tools, activity, activities to establish a high level of information national security of the state and increase it (M. Hnatko [2, p. 121]).

Conclusion. Summing up the results of the study of the ontological essence and components of the societal phenomenon of "information security", principles and functions of the information security of the state in the context of public administration science, we note that information security in a globalized information society plays a key role in the further civilizational development of mankind, as the problem of the modern information security means not only and not so much technical and technological measures to protect the information systems and networks, identify and eliminate various information threats, how much protection of the national information sovereignty of the state, information interests of the society and the man, maintenance of the socio-political, spiritual-cultural, moral-ethical and other interests of the citizens functioning in the information space, stability of the state system and political system of the country.

\section{References:}

1. Victoria Zhugan (2017). The doctrine of information security of Ukraine is only a declaration - experts [Doktryna informatsiynoyi bezpeky Ukrayiny - tse lyshe deklaratsiya - eksperty]. Online edition of Radio Liberty. URL : https://www.radiosvoboda.org/a/28336852.html 
2. Gnatko M. (2018). Informatsiyna natsional'na bezpeka derzhavy i rol' u niy politychnykh mifiv [Information national security of the state and the role of political myths in it]. Derzhava i pravo. Seriya : Politychni nauky. Vol. 82. C. 117-131. [Ukraine]

3. Kirichenko O. (2018). Informatsiyna natsional'na bezpeka derzhavy i rol' u niy politychnykh mifiv [Conceptual bases of formation of system of maintenance of information security of the state]. Vcheni zapysky universytetu "KROK". Seriya : Ekonomika Vol. 49. C. 19-26. [Ukraine]

4. Korzh I. (2016). Osnovni kryteriyi informatsiyi - predmeta informatsiynoyi funktsiyi derzhavy yak bezpekovoyi [The main criteria of information - the subject of the information function of the state as a security]. Pravo i suspil'stvo. Vol. 5. C. 108-115. [Ukraine]

5. Kochubey L. (2015). Informatsiyna bezpeka derzhavy: instrumenty zakhystu ukrayins'koho informatsiynoho polya (na prykladi osoblyvostey informatsiyno-komunikatsiynykh tekhnolohiy u suchasnomu Donbasi) [Information security of the state: tools for protection of the Ukrainian information field (on the example of features of information and communication technologies in modern Donbass]. Naukovi zapysky Instytutu politychnykh i etnonatsional'nykh doslidzhen' im. I. F. Kurasa. Vol. 3. C. 220237. [Ukraine]

6. Manuilov E., Kalinovsky Y. (2017). Aksiolohichnyy vymir informatsiynoyi bezpeky ukrayins'koyi derzhavy [Axiological dimension of information security of the Ukrainian state]. Visnyk Natsional'noho universytetu "Yurydychna akademiya Ukrayiny imeni Yaroslava Mudroho". Seriya : Filosofiya, filosofiya prava, politolohiya, sotsiolohiya. Vol. 3. C. 13-30. [Ukraine]

7. Nikiforov M., Pampukha I., Loza V. (2018). Analiz zahroz voyennoyi bezpeky derzhavy v informatsiynoyi sferi ta protydiyi yim $\mathrm{v}$ umovakh vedennya hibrydnoyi viyny [Analysis of threats to the military security of the state in the information sphere and counteraction to them in the conditions of conducting a hybrid war]. Zbirnyk naukovykh prats' Viys'kovoho instytutu Kyyivs'koho natsional'noho universytetu imeni Tarasa Shevchenka. Vol. 61. C. 135-142. [Ukraine]

8. Nishchimenko O. (2016). Informatsiyna bezpeka Ukrayiny na suchasnomu etapi rozvytku derzhavy i suspil'stva [Information security of Ukraine at the present stage of development of the state and society]. Nashe pravo. Vol. 1. C. 17-23. [Ukraine]

9. Oliynyk O. (2016). Pryntsypy zabezpechennya informatsiynoyi bezpeky Ukrayiny [Principles of information security of Ukraine]. Yurydychnyy visnyk. Povitryane i kosmichne pravo. Vol. 4. C. 321-328. [Ukraine]

10. Snitsarenko P., Sarichev Y., Tkachenko V. (2018). Zahal'noteoretychni peredumovy neobkhidnosti udoskonalennya chynnoho zakonodavstva Ukrayiny z pytan' informatsiynoyi bezpeky derzhavy [General theoretical prerequisites for the need to improve the current legislation of Ukraine on information security of the state]. Zbirnyk naukovykh prats' Tsentru voyenno-stratehichnykh doslidzhen' Natsional'noho universytetu oborony Ukrayiny imeni Ivana Chernyakhovs'koho. Vol. 1. C. 62-67. [Ukraine]

11. Toryanik V. (2016). Informatsiyna bezpeka yak skladova natsional'noyi bezpeky derzhavy: rol' ZMI v zabezpechenni informatsiynoho suverenitetu Ukrayiny [Information security as a component of national security: the role of the media in ensuring the information sovereignty of Ukraine]. Pravo i suspil'stvo. Vol. 2. C. 151-156. [Ukraine]

12. Turchak A. (2019). Osnovni skladovi informatsiynoyi bezpeky derzhavy [The main components of information security of the state]. Aspekty publichnoho upravlinnya. T. 7, Vol. 5. C. 44-56. [Ukraine]

13. Furashev V. (2012). Kiberprostir ta informatsiynyy prostir, kiberbezpeka ta informatsiyna bezpeka: sutnist', vyznachennya, vidminnosti [Cyberspace and information space, cybersecurity and information security: essence, definitions, differences]. Informatsiya i pravo. Vol. 2. C. 162-169. [Ukraine]

14. Panchenko, O. (2020). Panic as a factor of information security threat. Public Administration and Law Review, (2), 4-9. https://doi.org/10.36690/2674-5216-2020-2-4. 